Research Article

www.ijrap.net

\title{
SCREENING OF ANTIBACTERIAL ACTIVITY OF HYDROALCOHOLIC EXTRACT OF CYNODON DACTYLON
}

Solanki Renu*, Nagori Badri Prakash

Lachoo Memorial College of Science and Technology (Autonomous), Pharmacy Wing, Jodhpur, Rajasthan, India

Received on: 11/08/12 Revised on: 21/10/12 Accepted on: 04/11/12

\author{
*Corresponding author \\ E-mail: solankirenu@yahoo.com \\ DOI: 10.7897/2277-4343.03629 \\ Published by Moksha Publishing House. Website www.mokshaph.com \\ All rights reserved.
}

\begin{abstract}
Cynodon dactylon is a well-known plant used as a folk remedy in treatment of many symptoms and diseases like cramps, measles, tumors, wounds and warts. In this study the hydroalcoholic extract of Cynodon dactylon was investigated for their antibacterial activity against two gram positive bacteria (Staphylococcus aureus, Staphylococcus albus) and two gram-negative bacteria (Escherichia coli and Pseudomonas aeruginosa) using agarwell diffusion method (zone of inhibition) and micro-dilution method (minimum inhibitory concentration). Ciprofloxacin was taken as positive control. Hydroalcoholic extract of Cynodon dactylon was taken as test sample and hydroalcoholic solvent was taken as negative control in a ratio of 60:40 of water and ethanol. From the results of zone of inhibition, it was concluded that hydroalcoholic extract of Cynodon dactylon possess an effective antibacterial activity while from results of minimum inhibitory concentration, it was revealed that all tested bacterial strains were sensitive towards Cynodon dactylon extract.

Keywords: Cynodon dactylon, Antibacterial Activity, Agar-Well Diffusion Method, Micro-Dilution Assay Method.
\end{abstract}

\section{INTRODUCTION}

Infectious diseases are disorders caused by pathogenic microorganisms. These diseases are also called as communicable or transmissible diseases since they can be transmitted from one person to another via a vector or replicating agent. Bacterial diseases are a type of infectious diseases caused by pathogenic bacteria ${ }^{1}$. Millions of bacteria normally live in the intestine, on the skin and the genitalia. Bacterial diseases results when the harmful bacteria get into a body area, multiply there and thrash the body's defensive mechanism. Pathogenic bacteria can invade in the body through various routes like inhalation into nose and lungs, ingestion of food or through damage skin tissues. Once bacteria enter the body, the immune system of the body recognizes the bacteria as foreign intruder and tries to kill or stop them from multiplying. However, even a healthy immune system is not always able to stop the bacteria from reproducing and spreading. As a result bacteria thrive in the body and emit toxins which damage cells and tissues that consequently results in the symptoms of bacterial disease. Although pharmaceutical industries have developed number of new antibiotics in the last few decades but simultaneously the resistance to these drugs by microorganisms has also increased ${ }^{2}$. Due to increasing antibiotic resistance in microorganisms and synthetic antibiotics side effects, medicinal plants are now gaining popularity in the treatment of bacterial infections ${ }^{3}$. One of such plant considered of great importance is Cynodon dactylon (Linn.) Pers. It is a perennial grass of Poaceae family, has variety of medicinal properties like antiestrogenic, antimicrobial, anathematic, antiemetic, antipyretic, antidiabetic and antioxidant activities ${ }^{4-8}$ and it is found to be cultivated throughout the tropics and subtropics regions of the world. The present study was undertaken to analyze the antibacterial activity of hydroalcoholic extract of whole plant of $C$. dactylon.

\section{MATERIALS AND METHODS}

Plant material collection, authentication and extraction

The plant was collected from the nearby area of Shastri Circle, Jodhpur (Rajasthan), India. The plant was authenticated by Dr. P. J. Parmar, Joint Director, Botanical Survey of India, Arid Zone Regional Center, Jodhpur (Rajasthan) and a sample voucher of plant specimen (LMC/QA2) was deposited for future reference. Hydroalcoholic extract of $C$. dactylon was obtained using water and ethanol in 60:40 ratio. This extract was used to analyze the antibacterial activity.

\section{Microorganisms used}

The test microorganisms used in the study were gram positive bacteria Staphylococcus aureus, Staphylococcus albus and gram-negative bacteria Escherichia coli and Pseudomonas aeruginosa. The strains were maintained in sterile conditions and grown on nutrient agar.

\section{Preparation of standard bacterial suspension}

Antibacterial testing of C.dactylon hydroalcoholic extract was carried out by determining Zone of Inhibition through Agar-Well Diffusion Method and calculating Minimum Inhibitory Concentration through Micro Dilution Assay Method. Five well-isolated colonies of each of the test microorganism viz. S. aureus, S. albus, E. coli and $P$. aeruginosa were transferred aseptically in the tubes filled with sterile saline and then centrifuged thoroughly. The bacterial suspensions thus obtained were compared with the $0.5 \mathrm{McF}$ arland standard. $0.5 \mathrm{McF}$ arland was prepared by adding $0.5 \mathrm{ml}$ of a $1.175 \%(\mathrm{w} / \mathrm{v})$ barium chloride dihydrate $(\mathrm{BaCl} 2 \cdot 2 \mathrm{H} 2 \mathrm{O})$ solution to $99.5 \mathrm{ml}$ of $1 \%(\mathrm{v} / \mathrm{v})$ sulfuric acid. McFarland standard was checked by using a spectrophotometer with a $1-\mathrm{cm}$ light path. The absorbance 
at the wavelength of $625 \mathrm{~nm}$ was found to be 0.09 , which was within the limit of the standard absorbance of 0.08 to 0.1. A 0.5 McFarland adjusted suspension gives a count of $10^{8}$ colony forming units $(\mathrm{CFU}) / \mathrm{ml}^{9}$.

\section{Determination of zone of inhibition by agar-well} diffusion method

Four set of three sterile nutrient agar plates were taken for the study of zone of inhibition of the four test microorganisms. Agar plates were then inoculated with the respective test organisms. Three holes of $6 \mathrm{~mm}$ diameter were bored in the medium of each plate. Out of three holes, one hole was filled with Ciprofloxacin solution of $5 \mu \mathrm{g} / \mathrm{ml}$ concentration as the positive control, another hole with $500 \mu \mathrm{g} / \mathrm{ml}$ concentration of hydroalcoholic extract solution of C.dactylon as test while third hole was filled with the hydroalcoholic solution (blank) and was kept as negative control. Plates were then incubated at $37^{\circ} \mathrm{C}$ for $24 \mathrm{hrs}$. After the incubation time period, the plates were examined for the presence of zone of inhibition ${ }^{10-11}$.

\section{Determination of minimum inhibitory concentration by micro dilution assay method}

Eight dilutions of the extract ranging from $500-3.9$ $\mu \mathrm{g} / \mathrm{ml}$ were prepared using two fold serial dilution method. Standardized inoculum of microorganisms of 0.5 McFarland standard turbidity prepared was further diluted upto $1: 1000\left(10^{5} \mathrm{CFU} / \mathrm{ml}\right)$ by adding sterile saline. Diluted bacterial suspension and hydroalcoholic extract of C.dactylon were added into the wells of micro titer plates. Ciprofloxacin $(5-0.0097 \mu \mathrm{g} / \mathrm{ml})$ was used as the positive control and hydroalcoholic solution was used as the negative control while hydroalcoholic extract of C.dactylon was taken as test and then incubated at $37^{\circ} \mathrm{C}$ for $24 \mathrm{hrs}$. Microbial growth was determined at absorbance of $620 \mathrm{~nm}$ using the RT-2100C micro plate reader (Rayto Life and analytical Sciences Co. Ltd, Shenzhen, China). The MIC values were taken as the lowest concentration of the extract in the wells of the microtitre plate that showed no turbidity of the wells in the microtitre plate $e^{9,10}$.

Table 1: Antibacterial Activity of Crude Extract of Cynodon Dactylon by Agar-Well Diffusion Method

\begin{tabular}{|c|c|c|c|c|c|}
\hline & \multirow[t]{2}{*}{ Concentration } & \multicolumn{4}{|c|}{ Zone of Inhibition (mm) } \\
\hline & & S. aureus & S. albus & E. coli & P. aeruginosa \\
\hline Positive Control (Ciprofloxacin) & $5 \mu \mathrm{g} / \mathrm{ml}$ & $24 \pm 0.31$ & $21 \pm 0.28$ & $28 \pm 0.41$ & $22 \pm 0.32$ \\
\hline Test (C. dactylon extract) & $500 \mu \mathrm{g} / \mathrm{ml}$ & $13 \pm 0.17$ & $11 \pm 0.15$ & $14 \pm 0.21$ & $10 \pm 0.15$ \\
\hline Negative Control (Hydroalcohol) & $60: 40$ ratio & NA & NA & NA & NA \\
\hline
\end{tabular}

$\mathrm{NA}=$ No Activity, All values are Mean \pm Standard Deviation, $\mathrm{N}=3$ (the experiment was performed in triplicate)

Table 2: Antibacterial Activity of Crude Extract of Cynodon Dactylon by Micro-Dilution Assay Method

\begin{tabular}{|c|c|c|c|c|}
\hline & \multicolumn{4}{|c|}{ Minimum Inhibitory Concentration $(\mu \mathrm{g} / \mathrm{ml})$} \\
\hline & S. aureus & S. albus & E. coli & P. aeruginosa \\
\hline Positive Control & 0.313 & 0.156 & 0.019 & 0.625 \\
\hline Test (C. dactylon extract) & 125 & 125 & 62.5 & 250 \\
\hline Negative Control & NA & NA & NA & NA \\
\hline
\end{tabular}

\section{RESULT AND DISCUSSION}

Result of antibacterial activity of crude extract of $C$. dactylon by agar-well diffusion method is shown in table 1. From the results of zone of inhibition (Table 1), it was revealed that the hydroalcoholic extract of $C$. dactylon possess an effective and equipotent antibacterial activity against both gram positive and gram negative bacteria. Result of antibacterial activity of crude extract of $C$. dactylon by micro-dilution method is shown in table 2 . From the results of minimum inhibitory concentration (Table 2), it was observed that almost all tested bacterial strains were found sensitive towards the hydroalcoholic extract of C. dactylon.

The phytochemical tests of hydroalcoholic extract of $C$. dactylon showed presence of various phytoconstituents like alkaloids, carbohydrates, flavonoids, glycosides, proteins/amino acids, phytosterols and terpenes. Further studies are required to separate the active constituents and to evaluate their antibacterial activity.

\section{CONCLUSION}

The hydroalcoholic extract $C$. dactylon demonstrated a broad-spectrum of antibacterial activity against both gram-positive and gram-negative bacteria. This activity of the plant extract may be possibly due to phytoconstituents present in it. Bioactive compounds from the plant can therefore be used in the formulation of antimicrobial agents for the treatment of various bacterial infections. Thus the present experiment from the hydroalcoholic extract of $C$. dactylon has been scientifically proven to be beneficial as an antibacterial agent against specific bacterial infections.

\section{REFERENCES}

1. Khosravi A, Behzadi A. Evaluation of antibacterial activity of seed hull of Quercus barantii on some gram-negative bacteria. Pak J Med Sci 2006; 22:429-32.

2. Cohen ML. Epidemiology of Drug Resistance: Implications for a Post Antimicrobial Era. Biosci 1992; 257:1050-55.

3. Solanki R. Some medicinal plants with antibacterial activity. Int J Comp Pharm 2010; 4(10):1-4.

4. Chopra RN, Nayer SL, Chopra IC. Glossary of Indian Medicinal Plants. 4th ed. New Delhi: New Delhi Publication and Information Directorate; 1999.

5. Kirtikar KR, Basu BD. Indian medicinal plants. 3rd ed. New Delhi: Sri Satguru Publications; 2001.

6. Pal DK: Evaluation of CNS activities of aerial parts of Cynodon dactylon Pers. in mice. Acta Pol Pharm Drug Res 2008; 65: 37-43.

7. Pal DK, Kumar M, Chakrabarty P, Kumar S. Evaluation of antioxidant activity of aerial parts of Cynodon dactylon. Asian J Chem 2008; 20:2479-81.

8. Chaudhari Y, Mody HR, Vamshikrishna B. Acharya: Antibacterial activity of Cynodon dactylon on different bacterial pathogens isolated from clinical samples. Int J Pharm Studies and Res 2011; 2(1):16-20.

9. Jorgensen JH, Turnidge JD, Washington JA. Antibacterial susceptibility tests. In: Murray PR, Pfaller MA, Tenover FC, Baron EJ, Yolken RH, editors. Manual of clinical microbiology. 7th ed. Washington DC: ASM Press; 1999. p. 1526-43. 
Solanki Renu et al / IJRAP 3(6), Nov - Dec 2012

10. Bose S, Bose A. Antimicrobial activity of Acanthus ilicifolius. Int J Pharm Sci 2008; 70(6): 821-23.

11. Ahmet A, Medine G, Meryem S, Hatice O, Fikrettin S Antimicrobial effects of Ocimum basillicum (Labiatae) extract. Turk J Biol 2005; 29:155-60
Cite this article as:

Solanki Renu, Nagori Badri Prakash. Screening of antibacterial activity of Hydroalcoholic extract of Cynodon dactylon. Int. J. Res. Ayur. Pharm. 2012; 3(6):827-829

Source of support: Nil, Conflict of interest: None Declared 